\title{
Subversion of the B-cell compartment during parasitic, bacterial, and viral infections
}

Gwenoline Borhis ${ }^{1,2,3^{*}}$ and Yolande Richard ${ }^{1,2,3^{*}}$

\begin{abstract}
Recent studies on HIV infection have identified new human B-cell subsets with a potentially important impact on anti-viral immunity. Current work highlights the occurrence of similar B-cell alterations in other viral, bacterial, and parasitic infections, suggesting that common strategies have been developed by pathogens to counteract protective immunity. For this review, we have selected key examples of human infections for which B-cell alterations have been described, to highlight the similarities and differences in the immune responses to a variety of pathogens. We believe that further comparisons between these models will lead to critical progress in the understanding of B-cell mechanisms and will open new target avenues for therapeutic interventions.
\end{abstract}

Keywords: Memory B cells, MZ B-cells, BAFF, B-reg, Virus, Parasite

\section{Review}

\section{Introduction}

To maintain the integrity of an organism constantly challenged by pathogens, the immune system is endowed with a variety of cell types. B-cells exert a key role in both the innate and adaptive branches of immunity, through the production of protective or neutralizing antibodies (Abs), and are well suited to recognize invading pathogens or vaccine antigens (Ags). Depending on the pathogen and its route of entry, different B-cell subsets, follicular or innate B-cells, develop a specific differentiation program, namely a T-dependent (TD) or T-independent (TI) response [1]. Follicular (FO) B-cells are specialized for the adaptive response, and mainly recognize proteins, whereas marginal zone (MZ) B-cells and B1 cells support the innate response to non-protein Ags. FO B-cells populate follicles in secondary lymphoid organs, express mono-specific B-cell receptor (BCR) and require cognate interactions with Ag-activated $\mathrm{CD}_{4}^{+}$helper T-cells for initiating TD responses. This response, though slow to develop, generates a unique "serological memory" that protects from further insults by similar pathogens. In contrast, MZ B-cells reside in the spleen MZ, the sub-

\footnotetext{
* Correspondence: gwenoline.borhis@inserm.fr; yolande.richard@inserm.fr ${ }^{1}$ INSERM u1016, Cochin Institute, Department of Infection, Immunity and Inflammation, 27 rue du Faubourg St-Jacques, Roussy Bldg., Paris 75014, France

${ }^{2}$ CNRS, Paris UMR8104, France

${ }^{3}$ Université Paris Descartes, Sorbonne Paris Cité, Paris 75014, France
}

capsular area of lymph nodes, and the sub-epithelial area of mucosa, where they monitor invading blood-borne and mucosal pathogens [2-4]. MZ B-cells and B1 cells both express poly-specific, possibly self-reactive, BCR in combination with different innate-like receptors, which deliver co-activation signals to B-cells. Once activated they rapidly differentiate into short-lived extra-follicular plasma cells (PC) with the help of various innate cell types [2,5]. Bloodborne bacteria and viruses generally express TI and TD Ags, thereby eliciting both innate and adaptive responses.

$\mathrm{B}$-cells can also exert Ab-independent regulatory functions through cytokine production and/or cognate interactions with T-cells or myeloid cells in mice and humans [6-8]. Human regulatory B-cells (B-regs), displaying different phenotypic and functional features, can improve or dampen immune responses, depending on the pathological situation. During chronic infection by hepatitis B virus (HBV) or HIV-1, B-regs inhibit the virus-specific $\mathrm{CD}^{+}$T-cell responses $[9,10]$. B-cells can also act as regulators of early innate immunity to virus infection. Through the expression of LT $\alpha 1 \beta 2$, B-cells-probably innate B-cells according to their location-are mandatory for type I interferon (IFN)-mediated survival of mice infected by cytomegalovirus [11] or vesicular stomatitis virus [12]. In these mouse models, LT $1 \beta 2$-expressing B-cells provide critical signals for type I IFN production to subcapsular $\mathrm{CD}_{169^{+}}$macrophages in the draining lymph nodes, and for virus containment [12]. Pathogens known 
for escaping protective immunity through antigenic variation can also use B-cells as a silent reservoir, possibly favoring pathogen spread [13-15], or can alter the phenotypes and functions of B-cells. The latter is the theme of this review; here we provide examples of parasitic, bacterial, and viral infections where B-cells with unconventional phenotypes have been identified and are thought to modulate the efficiency of pathogen-specific $\mathrm{B}$ - and T-cell immune responses.

\section{Distinct B-cell subsets}

\section{FO B-cells in the establishment of long-lived memory}

The TD $\mathrm{Ab}$ response relies on the production of two kinds of effectors from FO naïve (IgD $\left.{ }^{\text {hi }} \operatorname{IgM}^{+} \mathrm{CD} 27^{-} \mathrm{CD} 21^{\text {int }}\right)$ B-cells: memory B-cells (MemB) and long-lived PC, who produce high-affinity Abs (Figure 1). This response occurs in lymphoid tissues, where naïve B-cells are organized in follicles in close contact with T-cell zones. Once activated by TD antigens (mainly proteins), naïve $\mathrm{B}$-cells rapidly proliferate at the T/B border and generate $\mathrm{PC}$ that locally produce low-affinity IgM within a few days [16]. Concomitantly activated B-cells produce germinal center (GC) founder cells, which proliferate in the center of follicles. These proliferating cells no longer express BCR and become $\mathrm{CD} 27^{\text {int }}$ and $\mathrm{Bcl6} 6^{+}$. After a set number of cell cycles, they become non-proliferating centrocytes expressing membrane switched and hyper-mutated BCR. Subsequent interactions of these centrocytes with a specialized T-cell subset, FO helper T-cells $\left(\mathrm{T}_{\mathrm{FH}}\right)$, and with $\mathrm{Ag}$ on FO dendritic cells (DC) determine the selection and survival of high-affinity B-cell clones [17-19]. Through cognate interactions and $\mathrm{T}_{\mathrm{FH}}$-produced cytokines (mostly IL21, but also IL4 and IL10), selected B-cell clones differentiate into MemB and PC precursors. After their trafficking into bone marrow, $\mathrm{PC}$ precursors constitute a pool of long-lived PC producing high-affinity Abs whereas MemB reside in extra-follicular areas in lymphoid tissues until further encounter with similar Ags. Thus, the TD response is a fine-tuned, multistep process, which constitutes an ideal target for pathogen-induced subversion, as suggested by the altered MemB phenotypes observed during many infections, particularly chronic ones.

\section{Human MZ B-cells and TI Ab response}

Human MZ B-cells can be distinguished from FO naïve B-cells as being $\operatorname{SIgM}^{\text {hi }} \mathrm{CD} 21^{\text {hi }} \mathrm{SIgD}^{+} \mathrm{CD} 23^{-} \mathrm{CD} 27^{+}$. These memory-like B-cells express a "pre-diversified" BCR repertoire, specialized in response to various TI-1 and TI-2

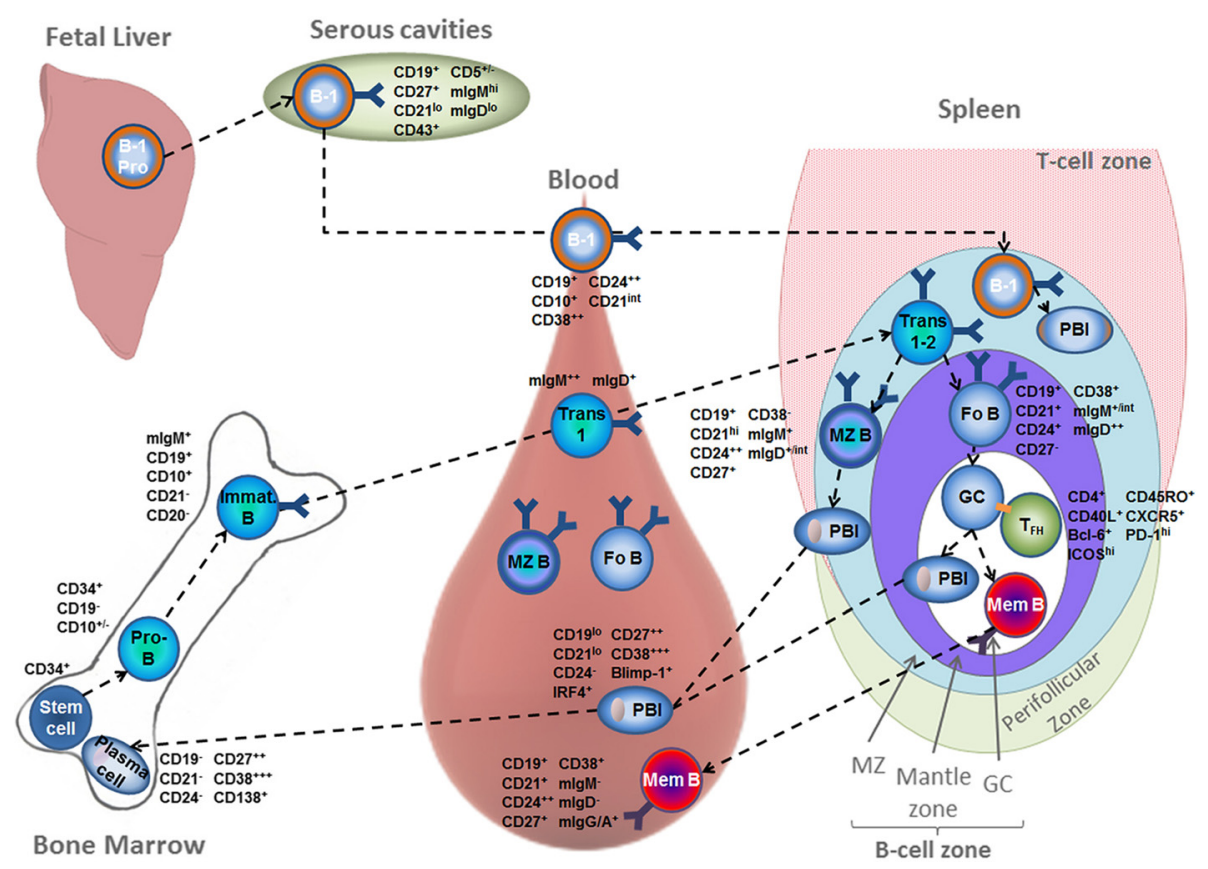

Figure 1 Differentiation and trafficking of innate and follicular B-cells. Mouse, and probably human, B-1 cells home to the serous cavities in steady state conditions and migrate to the spleen after activation by pathogens where they differentiate into natural Immunoglobulin (Ig) M-producing cells. Follicular (FO) B-cells are produced from bone marrow precursors that mature sequentially into pro-B and pre-B cells (not detailed) and immature mlgM ${ }^{+}$B-cells. Immature-transitional 1 (Trans 1) B-cells migrate through the blood into spleen marginal zone (MZ) where they mature into transitional 2 (Trans 2) B-cells. Based on the balance between BCR-Notch2 signals, they next differentiate into FO or MZ B-cells. MZ B cells secrete low affinity lgM after antigenic stimulation. In the germinal center (GC), FO helper T-cells $\left(T_{F H}\right)$ support the selection and survival of B-cell clones with high-affinity BCR. Once selected, these clones differentiate into two types of effector cells, memory B-cells (Mem B) and plasma cell precursors (plasmablasts, PBI), and leave the spleen. The PBI migrate into the bone marrow and constitute a pool of long-lived plasma cells producing high-affinity lg, whereas the Mem B migrate into extra-follicular areas in secondary lymphoid tissues. 
Ags $[4,20]$. Typical TI-2 Ags are bacterial capsular polysaccharides or highly repetitive motifs found in viral capsids, which cross-link the BCR. This potent BCR activation, along with innate cell signals, elicits a rapid differentiation of MZ B-cells into extra-follicular PCs [2]. Some TI-2 Ags can transiently induce non-productive GCs that fail to generate MemB [21]. In contrast, TI-1 Ags are more heterogeneous; they include lipopeptides, liposaccharides, microbial CpG DNA, viral RNA, and some viral coat proteins. TI-1 Ags deliver a synergic activation to MZ B-cells through their BCR and toll-like receptors (TLRs), which leads to their differentiation into PC. In the absence of TLR4, human MZ B-cells can recognize various unrelated molecules from a broad spectrum of microbes through binding to their TLR2/1 and TLR2/6 complexes [22]. However, prior BCR activation is required for enhancing MZ B-cell responsiveness to TLR ligands. For example, BCR cross-linking by protein A from Staphylococcus aureus enhances TLR2-mediated proliferation, in vitro [23].

The key role of MZ B-cells in response to microbial Ags is strongly supported by studies in aged and very young individuals. Incidence of invasive pneumococcal disease increases with age, particularly in individuals that are over 65 years old [24]. Likewise, children under 2-3 years of age are highly susceptible to bacterial infections and develop minimal long-lasting protection towards polysaccharide pneumococcal vaccines $[25,26]$. This inefficient $\mathrm{Ab}$ response correlates with altered organization and functions of the spleen MZ-like area or MZ B-cells [3,27-30]. Additionally, MZ B-cells can capture and import both viral particles and high molecular weight Ags into follicles, which accelerates the initiation of the adaptive response against pathogens and widens the repertoire of Ags in the GC [31]. Thus, MZ B-cells link the innate and adaptive immune responses.

\section{Human B1-like cells}

Numerous studies have aimed to identify human B1-like cells. Recently, Griffin et al. identified human B1-like cells as $\mathrm{CD} 20^{+} \mathrm{CD} 27^{+} \mathrm{CD} 43^{+} \mathrm{CD} 21^{\mathrm{lo}} \mathrm{CD} 23^{-}$B-cells, with $75 \%$ being $\mathrm{CD}^{+}[32,33]$. These cells represent a small fraction of B-cells in adult blood and typically have spontaneous IgM production, skewed BCR with constitutive signaling, efficient T-cell stimulation, and an absence of CD70 or CD69 expression after stimulation [33]. Human B1-like cells are enriched in phosphorylcholine-specific B-cells [32] and produce capsular polysaccharide-specific Abs following vaccination against Streptococcus pneumonia (Pneumo23) [34]. Along with MZ B-cells, B1-like cells are likely involved in the TI Ab response. However, specific changes in human B1-like cells during infection have not yet been described.

\section{Microbial and Parasite-induced B-cell changes}

Besides directly interacting with innate B-cells, microbial pathogens frequently modify their microenvironment and subvert the humoral response. Here, we discuss infections by selected widespread, mortality-causing parasites reported to induce or expand unconventional B-cell subsets (Table 1).

\section{B-cells in human Plasmodium infection}

Recent studies comparing various cohorts of individuals exposed to Plasmodium parasites, the causal agents of malaria, have revealed important changes in blood B-cell composition, in addition to T-cell hypo-responsiveness, short-lived protection by specific Abs, polyclonal B-cell activation, and an increase in total IgG during acute infection [35]. Reduced numbers of circulating MZ B-cells have been observed in children chronically exposed to Plasmodium parasites [36] and were associated with the well-established malaria-associated suppression of the anti-polysaccharide $\mathrm{Ab}$ response [37]. In adult women from high and low malaria-exposed countries, reduced proportions of blood MZ B-cells were correlated with lower levels of Plasmodium-specific plasma IgG [38]. Additionally, elevated plasma BAFF (B-cell activating factor belonging to tumor necrosis factor family) levels, reduced BAFF-R expression on blood B-cells, and increased numbers of circulating $\mathrm{CD} 10^{+} \mathrm{B}$-cells were independently reported during controlled human malaria infection and in acutely infected children $[36,39,40]$. Initially considered to be B-cell precursors mobilized into blood in response to BAFF over-production, several observations suggest that these $\mathrm{CD} 10^{+} \mathrm{B}$-cells might also include BAFF-induced CD10 ${ }^{+}$B-regs [35]: (i) in the murine model of Babesia microti infection, a Plasmodium-related model, $\mathrm{IL}_{10}{ }^{+} \mathrm{B}$-regs are induced that limit parasitespecific T-cell responses through expansion of regulatory T-cells $\left(\mathrm{T}_{\text {reg }}\right)$ [41]; (ii) BAFF was shown to expand $\mathrm{IL}^{+}{ }^{+}$ B-regs in healthy mice [42]; and (iii) monocytes exposed to the soluble fraction of malaria-infected erythrocytes in vitro strongly express BAFF and induce B-cell proliferation and IgG secretion [43].

Increased proportions of atypical $\left(\mathrm{CD} 21^{\mathrm{lo}} \mathrm{CD} 27^{-}\right) \mathrm{MemB}$, which conditionally express inhibitory Fc receptor-like-4 (FcRL4), are repeatedly observed during malaria infection. In endemic areas, atypical MemB from malaria-exposed individuals express FcRL4, in combination with enhanced expression of CD19, chemokine receptors, and activation markers [44-46]. In these individuals, both classical and atypical MemB can produce neutralizing Plasmodiumspecific IgG [45]. However, compared with classical MemB, atypical MemB are enriched in poly-reactive B-cells and recognize different Plasmodium-associated Ags [45]. Increased proportions of atypical MemB were also observed in women from malaria-endemic countries and correlate 
Table 1 Summary of the main changes in B-cell subsets during parasite and viral infections

\begin{tabular}{|c|c|c|c|c|c|c|}
\hline \multicolumn{7}{|l|}{ PATHOGENS } \\
\hline & $\begin{array}{l}\text { Plasmodium } \\
\text { falciparum or vivax }\end{array}$ & $\begin{array}{l}\text { Schistosomia } \\
\text { haematobium }\end{array}$ & Mycobacterium tuberculosis & HIV-1 /SIV & $\mathrm{HCV}$ & HBV \\
\hline Circulating BAFF levels & $\begin{array}{l}\text { Elevated Reduced } \\
\text { BAFF-R expression }\end{array}$ & ND & ND & $\begin{array}{l}\text { Increased during acute } \\
\text { phase. Associated to B-cell } \\
\text { lymphoma (chronic phase) }\end{array}$ & ND & ND \\
\hline \multicolumn{7}{|l|}{ Frequencies of B-cell subsets } \\
\hline $\begin{array}{l}\text { Immature-transtional CD10 } \\
\operatorname{lgM}^{+} \operatorname{lgD}{ }^{+} \text {CD27 }\end{array}$ & Increased & ND & ND & Increased (chronic) & ND & ND \\
\hline$M Z \lg M^{h i} \lg D^{+} C D 27^{+}$ & Reduced & Unchanged & ND & Decrease & ND & ND \\
\hline $\begin{array}{l}\text { Naive } \lg M^{+} \lg D^{\text {hi }} \mathrm{CD} 27^{-} \\
\text {CD21 int }\end{array}$ & ND & Decreased & ND & Variable & Variable & ND \\
\hline $\begin{array}{l}\text { Resting Mem IgD }{ }^{-} \mathrm{CD} 27^{+} \\
\mathrm{CD}^{+} 1^{+}\end{array}$ & Decreased & Unchanged & ND & Decreased & Decreased & ND \\
\hline $\begin{array}{l}\text { Activated Mem IgD-CD27 } \\
\text { CD21 }\end{array}$ & ND & Increased & ND & Increased & ND & ND \\
\hline $\begin{array}{l}\text { Atypical Mem SlgG/A }{ }^{+} \\
\mathrm{CD}^{-} 7^{-C D} 21^{-}\end{array}$ & $\begin{array}{l}\text { increased FcRL4 }{ }^{+}, \\
\text {Polysaccharide IgG }\end{array}$ & Increased & ND & $\begin{array}{l}\text { Increased FcRL4+ virus- } \\
\text { specific Abs? }\end{array}$ & $\begin{array}{l}\text { Increased, CD95 } \\
\text { IgG producers }\end{array}$ & ND \\
\hline \multirow[t]{2}{*}{ Regulatory B-cells } & \multirow[t]{2}{*}{ CD10 Increased? } & $\begin{array}{l}\text { CD1 } \mathrm{d}^{\text {hi }}, \text { IL } 10^{+} \text {, Induce } \\
\text { T-reg Suppress IFNy and } \\
\text { IL17 production }\end{array}$ & \multirow[t]{2}{*}{$\begin{array}{l}\text { CD1 } d^{\text {hi }} C D 5^{+} \text {, no IL } 10 \text { or TGF } \beta \\
\text { Suppression of IL } 17 / 22 \text { through } \\
\text { cognate interactions }\end{array}$} & \multirow[t]{2}{*}{$\begin{array}{l}\text { CD } 38^{\text {hi }} C D 24^{\text {hi }} C D 27^{-} I L 10^{+} \\
\text {Suppress HIV-specific CD8 } \\
\text { T-cell responses }\end{array}$} & \multirow[t]{2}{*}{ ND } & \multirow[t]{2}{*}{$\begin{array}{l}\text { CD38 } 8^{\text {hi }} C D 24^{\text {hi }} C D 27^{-} \text {IL } 10^{+} \text {, } \\
\text { Suppress HIV-specific CD8 } \\
\text { T-cell responses }\end{array}$} \\
\hline & & $\begin{array}{l}\text { CD24 } 4^{\text {hi }} \mathrm{CD} 27^{+} \text {Produce } \\
\text { TGF } \beta \text { and induce Treg }\end{array}$ & & & & \\
\hline \multirow[t]{3}{*}{ Additionnal Remarks } & $\begin{array}{l}\text { Pregenany exacerbates } \\
\text { atypical Mem expansion }\end{array}$ & $\begin{array}{l}\text { Impaired TNFa production } \\
\text { by B-cells, even in treated } \\
\text { patients }\end{array}$ & $\begin{array}{l}\text { Impaired responses of } \\
\text { monocytes \& } C D 11 C^{+} D C\end{array}$ & Impaired fonctions of DC & $\begin{array}{l}\text { Impaired responses } \\
\text { of monocytes \& DC }\end{array}$ & $\begin{array}{l}\text { Impaired responses of } \\
\text { monocytes \& DC }\end{array}$ \\
\hline & \multirow[t]{2}{*}{ T-cell hyporesponsiveness } & \multirow{2}{*}{$\begin{array}{l}\text { Impaired responses of } \\
\text { CD11 } c^{+} D C \text { T-cell } \\
\text { hyporesponsiveness }\end{array}$} & \multirow[t]{2}{*}{ T-cell hyporesponsiveness } & Increased in Slan DC & \multirow{2}{*}{$\begin{array}{l}\text { Impaired CD8 } \\
\text { T-cell responses }\end{array}$} & \multirow{2}{*}{$\begin{array}{l}\text { Impaired CD8 T-cell } \\
\text { responses }\end{array}$} \\
\hline & & & & $\begin{array}{l}\text { Strong depletion of CD4 } \\
\text { T-cells Impaired CD8 T-cell } \\
\text { responses }\end{array}$ & & \\
\hline
\end{tabular}

Abs: antibodies; DC: dendritic cells; HBV: hepatitis B virus; HCV: hepatitis C virus; HIV: human immunodeficiency virus; Mem: memory; MZ: marginal zone; ND: Not documented; T-reg: regulatory T-cells; SIV: simian immunodeficiency virus. 
with the increases in Plasmodium-specific plasma IgG [38]. However, natural resistance to malaria in the Fulani ethnic group is correlated with increased proportions of both PC and activated MemB, thought to be the major source of protective Abs [47].

Despite similarities with tissue-like MemB [48,49], atypical MemB in malaria-exposed individuals also have features of PC precursors and might contribute to anti-malarial immunity, rather than to immune exhaustion as they do in HIV-infected patients [45,50]. Atypical MemB observed during the acute phase of controlled human malaria infection are FcRL4 ${ }^{-}$[40], suggesting that FcRL4 expression might be a consequence of repeated exposure to pathogen-associated Ags. Because FcRL4 reduces BCR signaling but enhances responsiveness to CpG [51], atypical MemB might be highly sensitive to Plasmodiumexpressed non-classical TLR9 ligands [52]. Alternatively, atypical MemB might develop in response to different signaling pathways during infections by Plasmodium and HIV. In controlled human malaria infection, BAFF was recently proposed as a key factor in B-cell changes [40]. Similarly, BAFF overproduction was reported in macaques acutely infected with SIV [53] and in primary HIV-infected patients [54] and was associated with changes in B-cell subsets. The cellular origin of atypical $\mathrm{MemB}$, the mechanisms that drive their expansion, and their capacities to release neutralizing pathogen-specific Abs during HIV infection vs. Plasmodium infection remain to be determined.

\section{B-cells in human schistosomiasis}

Chronic infection with Schistosoma haematobium causes general immune activation, T-cell hypo-responsiveness, and impaired myeloid DC responses [55,56]. Schistosomiasisinfected children have increased amounts of atypical and activated MemB but decreased levels of naïve B-cells compared with uninfected children, with no differences in their resting memory or MZ B-cell frequencies. Additionally, infection by schistosomes reduces tumor necrosis factor $\alpha$ (TNF $\alpha$ ) production in BCR-stimulated MemB subsets, and this might contribute to decreased pathogen-specific Th1 responses. Anti-schistosome treatment with praziquantel restores normal proportions of memory and naïve B-cells but only partially corrects TNF $\alpha$ production [57]. Two recent articles establish that blood $\mathrm{CD} 1 \mathrm{~d}^{\mathrm{hi}} \mathrm{CD} 27^{-}$and $\mathrm{CD} 24^{\mathrm{hi}} \mathrm{CD} 27^{+} \mathrm{B}$-regs are more numerous in schistosomeinfected individuals than in healthy donors. Whereas CD1d ${ }^{\text {hi }}$ B-regs overexpress IL10, increase the frequency of $\mathrm{IL} 10^{+} \mathrm{T}_{\text {reg }}$, and suppress effector T-cell cytokines (e.g., IFNY and IL17), the CD24 ${ }^{\text {hi }}$ B-regs express membrane TGF $\beta 1$ and favor expansion of Foxp $3^{+} \mathrm{T}_{\text {reg }}\left(\mathrm{CD} 25^{+} \mathrm{Foxp}^{+}\right)$. Likely expanded through different mechanisms, these two populations synergize to dampen the schistosome-specific T-cell responses $[58,59]$.

\section{B-cells and infection by Mycobacterium tuberculosis}

Previous studies on cellular immune responses during Mycobacterium tuberculosis infection have established that IL17- and IL22-producing cells, CD4 ${ }^{+} \mathrm{T}$-cells, and NK cells are mandatory for protective immunity against Mycobacterium [60-62]. However, B-cells are now considered key players in shaping the Mycobacterium-specific response through cognate interactions and cytokine production. They are a major component of lung granulomas in M. tuberculosis infection and are critical for parasite containment [63]. Human B-cells in pleural fluid and lung ectopic follicles enhance the functional activation of IL17 (Th17)- and IL22 (Th22)-expressing M. tuberculosisspecific T-cells but have no influence on Th1 expansion or IFNy production [64]. A restricted $\mathrm{CD} 1 \mathrm{~d}^{\text {hi }} \mathrm{CD}^{+}$B-cell subset inhibits Th17/22 development through cognate interactions but not by supplying of IL10 or TGF $\beta$. These B-cells also accumulate in the lung ectopic follicles and blood of patients with active tuberculosis. The percentage of circulating $\mathrm{CD} 1 \mathrm{~d}^{\mathrm{hi}} \mathrm{CD}^{+}$B-cells within total B-cells inversely correlated with that of Th17 in these patients [65]. Although M. tuberculosis lysates enhance the suppressive functions of B-cells, it is not known which of the pathogen-specific Ags are responsible. In summary, different B-cell subsets with enhancing or suppressive functions modulate pathogen-specific T-cell responses and pathogen containment. Additional work is needed to identify which mechanisms (e.g., BCR, TLR2, and TLR9) control the expansion of suppressive B-cells in patients with different clinical manifestations. The putative contributions of innate (MZ or B1-like) B-cells and ectopic follicle B-cells to early and late Ab-driven protection, respectively, remain to be determined. Further study of Ab-independent B-cell functions may aid in developing new vaccine strategies.

\section{Multitasking B-cells during Salmonella infection}

Bacteremia caused by Salmonella remains a critical human health problem, particularly in immune-compromised individuals and pregnant women. Both mouse and human B-cells are susceptible to Salmonella infection and can act as pathogen reservoirs, contributing to its spread [66]. The consequences of this infection on human B-cell physiology and disease progression are yet unknown. In mice, B-cells act as antigen-presenting cells required for protective T-cell responses [67]. However, more recent data show that B-regs, with PC attributes, exert immunosuppressive functions during Salmonella infection by supplying IL10 and/or IL35 [68]. Although the transposition of data from mice to humans is probably premature, these findings might offer interesting possibilities for treatment of Salmonella infections and also increase our understanding of specific B-reg expansion. 


\section{B-cells during viral infection}

Developing a vaccine against HIV-1 and understanding why the neutralizing $\mathrm{Ab}$ response is globally inefficient remains a challenge. Defaults in the HIV-specific Ab response were widely thought to result from a loss in $\mathrm{CD}^{+}$ T-cells, but recent in-depth examinations of the B-cell population during pathogenic and non-pathogenic HIV/ SIV infection have challenged this idea. These pioneering studies have largely contributed to change our global understanding of the role of B-cells.

\section{B-cells during HIV/SIV infection}

B-cell dysfunctions are now considered to be a central feature of HIV infection and an important pathogenic mechanism [69-71]. Although B-cell hyper-activation, including centro-follicular hyperplasia, and hypergammaglobulinemia, with IgG1 being the most deregulated, were among the first symptoms described in HIV-infected patients [72-74], the role of B-cells in HIV/SIV progression has been largely underappreciated until recently. One extremely puzzling issue in HIV infection is the global inefficiency of the HIV-induced Ab response. Cumulative data reveal that circulating virus-specific Abs are detectable by one month of infection, whereas neutralizing Abs are undetectable until after 3 months. Broadly neutralizing Abs generally develop after one or two years and in only $10-30 \%$ of untreated HIV-infected patients [75]. Most neutralizing Abs are directed against HIV gp120 or gp41 proteins or their binding sites on CD4, CCR5, or CXCR4, and have features of poly-reactive or self-reactive Abs [76]. Along with the virus-specific $\mathrm{Ab}$ response, the humoral response to non-HIV Ags is strongly impaired, resulting in a decreased response to natural or vaccine TI and TD Ags as early as during the acute phase of infection [71,77]. Together, these data suggest that both the innate (TI) and virus-specific (TD) arms of the $\mathrm{Ab}$ response are impaired during HIV infection.

Chronically HIV-infected patients are reported to experience a loss in circulating MZ-like B-cells, associated with an impaired response to pneumococcal Ags [77,78]. Similarly, following infection, primary SIV-infected macaques have reduced proportions of MZ B-cells, not only in blood but also in spleen and peripheral lymph nodes [79]. Additionally, increases in circulating IgM and IgG levels and in PC numbers were observed in the spleen $\mathrm{MZ}$ of these animals from two weeks post-infection. Thus, virus-activated MZ B-cells likely differentiate into PC. This idea is consistent with a report showing that gp120-activated MZ-like B-cells rapidly produce IgG and IgA [80]. However, the most striking effect of HIV infection occurs within the MemB pool. Resting MemB constitute the predominant fraction of blood MemB in healthy donors, with low percentages of activated and atypical MemB [81]. In contrast, there is a paucity of resting MemB while both activated and atypical MemB are over-represented in the blood of chronically HIVinfected patients [70]. A similar decrease in resting MemB has been reported during pathogenic SIV infection $[53,79,82]$, and this loss is concomitant with BAFF overproduction during the acute phase [53].

In chronically HIV-infected patients, atypical MemB are exhausted B-cells that express FcRL4 and other inhibitory receptors and are unresponsive to BCR triggering [50]. These cells, however, are highly responsive to TLR9 ligands and, therefore, could play a role in Ab or cytokine production. FcRL4 expression appears to protect MemB from the deleterious effects of chronic infection or inflammation [51]. Within the atypical MemB pool, HIV-specific Abs are enriched, and their production might be further enhanced by treatment with shortinterfering RNA targeting FCRL4 or SIGLEC-6 $[50,83]$. FcRL4 expression and TGF $\beta 1$ production are induced by the binding of recombinant gp120 to the $\alpha 4 \beta 7$ integrin expressed by naïve B-cells [84]. Co-culture of B-cells with $\mathrm{CD} 4^{+} \mathrm{T}$-cells from HIV-infected donors similarly upregulates B-cell FcRL4 expression. Interactions between gp120 and $\alpha 4 \beta 7$ also reduce B-cell proliferative responses and CD80 expression [84]. The latter is consistent with our previous data showing decreased CD80, but not CD86, expression in GC B-cells from chronically HIV-infected patients [85]. Thus HIV-1 might impair both the BCR responses and co-stimulation abilities of B-cells, at least during the chronic phase of infection. Moreover, X4 gp120 proteins strongly reduce B-cell chemotaxis to not only CXCL12 but also to CCL20 and CCL21 by crossdesensitization of CCR6 and CCR7. Additionally, they induce CD62L cleavage and enhance MemB CD95 expression [86]. In summary, HIV has developed various envelope-based strategies to subvert B-cell responses, survival, and trafficking.

A key checkpoint for adaptive B-cell responses is the $\mathrm{GC}$ reaction leading to the generation of $\mathrm{MemB}$ and long-lived PC precursors. Although GC hyperplasia during pathogenic HIV/SIV infection was described long ago $[85,87,88]$, the precise impact of the virus on GC B-cells remains elusive. We previously described the well-conserved organization and polarization of GC from the in splenic, nodular and intestinal follicles during primary SIV infection [53,79]. Levesque et al. observed GC fragmentation in primary HIV-infected patients [89], but generally GC involution is more frequent during the chronic and advanced phases of HIV infection when CXCR4 variants are present [85]. Similarly, early GC disruption occurs after SIV infection of Indian rhesus macaques, a model of rapid disease progression, [90] but not in the more typical models using cynomolgus or Chinese rhesus macaques [53,91].

Recent progress on the characterization of $\mathrm{T}_{\mathrm{FH}}$ cells has clarified some points. First, circulating or nodular 
$\mathrm{T}_{\mathrm{FH}}$ cells are infected by HIV/SIV similarly to, or even more strongly than other $\mathrm{CD} 4^{+} \mathrm{T}$-cells, but survive longer despite continuous exposure to virus [53,92-94]. Second, during the acute phase of infection $\mathrm{T}_{\mathrm{FH}}$ cells are moderately expanded in most individuals, with a correlation between tissue viral load and percentages of $\mathrm{T}_{\mathrm{FH}}$ cells [95]. In contrast, chronically HIV-infected individuals and SIV-infected animals have strong interindividual variation in their percentages of $\mathrm{T}_{\mathrm{FH}}$ cells [92-94]. However, conflicting results have been reported regarding the correlation between viral load and proportions of $\mathrm{T}_{\mathrm{FH}}$ during the chronic phase of infection $[92,93]$. Based on the proportions of $\mathrm{CD} 4^{+} \mathrm{CD} 45 \mathrm{RO}^{+}$or $\mathrm{CD} 4^{+} \mathrm{PD} 1^{\text {hi }} \mathrm{T}$ cells in $\mathrm{GC}$, it was possible to correlate $\mathrm{T}_{\mathrm{FH}}$ and GC hyperplasia in SIV-infected macaques and in the lymph nodes of chronically HIV-infected patients by in situ analysis $[53,91,93]$. In summary, during HIV/ SIV infection $\mathrm{T}_{\mathrm{FH}}$ cells are expanded and GCs are correctly polarized but the virus-specific response is delayed, and when it occurs, it provides relatively inefficient protection.

These paradoxical findings suggest that more subtle dysfunctions of GC B-cells, $\mathrm{T}_{\mathrm{FH}}$ cells, or of their dialog occur during HIV infection and impair either the generation (within GC) or the survival and trafficking of effector B-cells (MemB or PC). The production of MemB with "alternate" phenotypes is consistent with a dysfunction of GC B-cells but might coexist with other impairments. Given that the virus is able to replicate within $\mathrm{T}_{\mathrm{FH}}$ cells, gp120, Tat, and Nef proteins might be locally overproduced and interfere with the GC reaction. Indeed, Nef was shown to affect Ig class switching [96], and soluble Tat selectively increases CD40-mediated proliferation of GC B-cells [97]. In-depth phenotypic, molecular, and functional analyses of B-cell and T-cell subsets within $\mathrm{GC}$ and at the follicular border during the priming phase are required for a better understanding of the HIVinduced defaults that cause inappropriate $\mathrm{Ab}$ responses.

In this already complex situation, a new B-cell subset with regulatory functions has been recently identified. This population with a $\mathrm{CD} 19^{+} \mathrm{CD} 38^{\text {hi }} \mathrm{CD} 24^{\text {hi }} \mathrm{PD}-\mathrm{L}^{+}\left(\mathrm{CD} 27^{-}\right)$ phenotype spontaneously secretes IL10 and inhibits CD8 ${ }^{+}$ T-cell proliferation and the HIV-specific cytotoxic response in antiretroviral-treated or untreated HIV-infected patients [9]. Besides IL10, PD-L1/PD1 interactions are assumed to critically contribute to $\mathrm{CD} 8^{+}$T-cell exhaustion. Patients with advanced HIV-disease also have increased proportions of circulating $\mathrm{CD} 10^{+}$immature-transitional B-cells [98]. Because IL7 and BAFF plasma levels were elevated in these patients $[98,99]$, bone marrow dysfunctions and/or lymphopenia are thought to induce $\mathrm{CD} 10^{+} \mathrm{B}$-cell mobilization into the periphery. Moreover, our data suggest that $\mathrm{CD}_{10}{ }^{+} \mathrm{CD} 38^{+} \mathrm{SIgD}^{+} \mathrm{B}$-cells, which are more numerous in HIV-infected patients with a high Epstein-Barr virus (EBV) viral load and a strong depletion of resting MemB, might constitute an alternate EBV reservoir [100]. Because $\mathrm{EBV}^{+} \mathrm{B}$-cell lymphomas occur with a higher incidence in HIV-infected individuals than in the general population [101], the contribution of these $\mathrm{CD} 10^{+} \mathrm{B}$-cells should be further examined.

\section{B-cells during hepatitis infection}

Similarly to infection with HIV, infection with HBV or hepatitis $\mathrm{C}$ virus $(\mathrm{HCV})$ is associated with polyclonal B-cell activation. When produced during the acute phase of infection, neutralizing Abs are associated with viral clearance [102]; unfortunately they frequently develop only during the chronic phase [103]. In chronically HCV-infected patients, B-cell dysfunction is reflected by IgG1 restriction, with low-titer and delayed-onset Ab responses [104]. Loss in resting MemB was associated with increased proportions of atypical MemB in HCV-infected patients, regardless of cirrhosis or hepatocellular carcinoma. This increase is likely present as early as during the acute phase of $\mathrm{HCV}$ infection. These atypical MemB are hypo-proliferative in response to $\mathrm{CD} 40$ or $\mathrm{BCR}$ stimulation but produce high amounts of IgG $[105,106]$. Increased MemB IgG production was observed in chronically HBV- and HCV-infected patients [107]. HCV is the only hepatitis infection model in which B-cell infection by particular virus quasi-species has been strongly demonstrated [108] and shown to be important for disease outcome [109]. In chronically HCVinfected patients, elevated levels of serum BAFF have been associated with autoimmunity [110]

HBV core Ag has the unique capacity to stimulate BCR in a non-Ag specific manner leading to sustained Bcell activation in chronically HBV-infected patients $[107,111]$. Although an extensive phenotypic and functional analysis of B-cells in HBV-infected patients is still lacking, Das et al. recently identified a unique subset of CD38 ${ }^{\text {hi }} \mathrm{CD} 24^{\mathrm{hi}} \mathrm{CD} 27^{-}$B-regs, whose frequency correlates with spontaneous flares of liver disease, viral load, and serum IL10 levels. This B-cell population inhibits virus-specific $\mathrm{CD}^{+} \mathrm{T}$-cell responses, but dampens liver inflammation through IL10 production [10].

\section{Conclusion}

This review highlights how infections by pathogens with strongly different physiopathology lead to similar changes in B-cell phenotypes but can differently alter protective responses. As previously shown in HIV-1-infected patients, these pathogens preferentially impair the MemB compartment and frequently induce B-reg subsets that inhibit either $\mathrm{CD}^{+}$(parasites) or $\mathrm{CD}^{+}$(virus) $\mathrm{T}$-cell responses. Remaining questions include the origin (MZ or FO B-cells), the mechanisms of induction, and the functional abilities of atypical MemB in various infections. Understanding the physiopathological role of B-cells during infection is 
important, and advances in one model of infection should benefit others.

\author{
Abbreviations \\ Ab: Antibody; Ag: Antigen; BAFF: B cell-Activating Factor belonging to the \\ TNF Family; BCR: B-Cell Receptor; B-reg: Regulatory B-cells; DC: Dendritic Cell; \\ EBV: Epstein-Barr virus; FO: Follicular; GC: Germinal Center; HBV: Hepatitis B \\ Virus; HCV: Hepatitis C Virus; HIV: Human Immunodeficiency Virus; \\ Ig: Immunoglobulin; MemB: Memory B-cell; MZ: Marginal Zone; PC: Plasma \\ Cell; SIV: Simian Immunodeficiency Virus; TD: T-cell Dependent; $T_{F H}$ : Follicular \\ Helper T-cell; TI: T-cell independent; TLR: Toll-like Receptor; T-reg: Regulatory \\ T-cells.
}

\section{Competing interests}

The authors declare that they have no competing interests.

\section{Authors' contributions}

GB and YR wrote the review and made the figure and table. Both authors read and approved the final manuscript.

\section{Acknowledgements}

Authors are supported by the CNRS, INSERM, Université Paris Descartes and by grants from the Agence Nationale de Recherche sur le SIDA et les Hépatites Virales (ANRS), the foundation "Aide à la Recherche sur la Sclérose en Plaques" (ARSEP) and the Federation pour la Recherche sur le Cerveau (FRC). GB is a post-doctoral researcher supported by ANRS and ARSEP.

\section{Received: 7 October 2014 Accepted: 24 February 2015 Published online: 26 March 2015}

\section{References}

1. Vinuesa CG, Chang PP. Innate B cell helpers reveal novel types of antibody responses. Nat Immunol. 2013;14(2):119-26.

2. Cerutti A, Cols M, Puga I. Marginal zone B cells: virtues of innate-like antibody-producing lymphocytes. Nat Rev Immunol. 2013;13(2):118-32.

3. Garraud O, Borhis G, Badr G, Degrelle S, Pozzetto B, Cognasse F, et al. Revisiting the B-cell compartment in mouse and humans: more than one B-cell subset exists in the marginal zone and beyond. BMC Immunol. 2012;13:63.

4. Weill JC, Weller S, Reynaud CA. Human marginal zone B cells. Annu Rev Immunol. 2009;27:267-85.

5. Magri G, Miyajima M, Bascones S, Mortha A, Puga I, Cassis L, et al. Innate lymphoid cells integrate stromal and immunological signals to enhance antibody production by splenic marginal zone B cells. Nat Immunol. 2014:15(4):354-64.

6. Lund FE, Randall TD. Effector and regulatory B cells: modulators of CD4+ T cell immunity. Nat Rev Immunol. 2010;10(4):236-47.

7. Mauri C, Ehrenstein MR. The 'short' history of regulatory B cells. Trends Immunol. 2008:29(1):34-40.

8. DiLillo DJ, Matsushita T, Tedder TF. B10 cells and regulatory B cells balance immune responses during inflammation, autoimmunity, and cancer. Ann N Y Acad Sci. 2010;1183:38-57.

9. Siewe B, Stapleton JT, Martinson J, Keshavarzian A, Kazmi N, Demarais PM, et al. Regulatory $B$ cell frequency correlates with markers of HIV disease progression and attenuates anti-HIV CD8(+) T cell function in vitro. J Leukoc Biol. 2013;93(5):811-8.

10. Das A, Ellis G, Pallant C, Lopes AR, Khanna P, Peppa D, et al. IL-10-producing regulatory $B$ cells in the pathogenesis of chronic hepatitis $B$ virus infection. J Immunol. 2012;189(8):3925-35.

11. Schneider K, Loewendorf A, De Trez C, Fulton J, Rhode A, Shumway H, et al. Lymphotoxin-mediated crosstalk between B cells and splenic stroma promotes the initial type I interferon response to cytomegalovirus. Cell Host Microbe. 2008;3(2):67-76.

12. Moseman EA, lannacone M, Bosurgi L, Tonti E, Chevrier N, Tumanov A, et al. $B$ cell maintenance of subcapsular sinus macrophages protects against a fatal viral infection independent of adaptive immunity. Immunity. 2012:36(3):415-26.

13. Castro-Eguiluz D, Pelayo R, Rosales-Garcia V, Rosales-Reyes R, Alpuche-Aranda C, Ortiz-Navarrete V. B cell precursors are targets for Salmonella infection. Microb Pathog. 2009:47(1):52-6.
14. McElroy DS, Ashley TJ, D'Orazio SE. Lymphocytes serve as a reservoir for Listeria monocytogenes growth during infection of mice. Microb Pathog. 2009;46(4):214-21.

15. Thorley-Lawson DA. Epstein-Barr virus: exploiting the immune system. Nat Rev Immunol. 2001; 1 (1):75-82.

16. Liu YJ, Zhang J, Lane PJ, Chan EY, MacLennan IC. Sites of specific B cell activation in primary and secondary responses to $T$ cell-dependent and $T$ cell-independent antigens. Eur J Immunol. 1991;21(12):2951-62.

17. Nutt SL, Tarlinton DM. Germinal center B and follicular helper T cells: siblings, cousins or just good friends? Nat Immunol. 2011;12(6):472-7.

18. McHeyzer-Williams $L$, Pelletier N, Mark L, Fazilleau N, McHeyzer-Williams MG. Follicular helper T cells as cognate regulators of B cell immunity. Curr Opin Immunol. 2009;21(3):266-73.

19. Crotty S. Follicular helper CD4 T cells (TFH). Annu Rev Immunol. 2011;29:621-63.

20. Weller S, Braun MC, Tan BK, Rosenwald A, Cordier C, Conley ME, et al. Human blood IgM "memory" B cells are circulating splenic marginal zone B cells harboring a prediversified immunoglobulin repertoire. Blood. 2004;104 (12):3647-54.

21. GarciadeVinuesa C, O'Leary P, Sze DM, Toellner KM, MacLennan IC T-independent type 2 antigens induce B cell proliferation in multiple splenic sites, but exponential growth is confined to extrafollicular foci. Eur J Immunol. 1999;29(4):1314-23.

22. Wetzler LM. The role of Toll-like receptor 2 in microbial disease and immunity. Vaccine. 2003;21 Suppl 2:555-60

23. Bekeredjian-Ding I, Inamura $\mathrm{S}$, Giese $\mathrm{T}$, Moll $H$, Endres $\mathrm{S}$, Sing $\mathrm{A}$, et al. Staphylococcus aureus protein A triggers $T$ cell-independent $B$ cell proliferation by sensitizing B cells for TLR2 ligands. J Immunol. 2007;178(5):2803-12.

24. Artz AS, Ershler WB, Longo DL. Pneumococcal vaccination and revaccination of older adults. Clin Microbiol Rev. 2003:16(2):308-18.

25. Giebink GS. The prevention of pneumococcal disease in children. N Engl J Med. 2001;345(16):1177-83.

26. Overturf GD. Pneumococcal vaccination of children. Semin Pediatr Infect Dis. 2002;13(3):155-64.

27. Timens W, Boes A, Rozeboom-Uiterwijk T, Poppema S. Immaturity of the human splenic marginal zone in infancy. Possible contribution to the deficient infant immune response. J Immunol. 1989;143(10):3200-6.

28. Shi Y, Yamazaki T, Okubo Y, Uehara Y, Sugane K, Agematsu K. Regulation of aged humoral immune defense against pneumococcal bacteria by lgM memory B cell. J Immunol. 2005;175(5):3262-7.

29. You Y, Myers RC, Freeberg L, Foote J, Kearney JF, Justement LB, et al. Marginal zone $B$ cells regulate antigen capture by marginal zone macrophages. J Immunol. 2011;186(4):2172-81.

30. You Y, Zhao H, Wang Y, Carter RH. Cutting edge: primary and secondary effects of CD19 deficiency on cells of the marginal zone. J Immunol. 2009:182(12):7343-7.

31. Cinamon G, Zachariah MA, Lam OM, Foss Jr FW, Cyster JG. Follicular shuttling of marginal zone B cells facilitates antigen transport. Nat Immunol. 2008;9(1):54-62.

32. Griffin DO, Holodick NE, Rothstein TL. Human B1 cells in umbilical cord and adult peripheral blood express the novel phenotype CD20+ CD27+ CD43+ CD70. J Exp Med. 2011;208(1):67-80.

33. Perez-Andres M, Grosserichter-Wagener C, Teodosio C, van Dongen JJ, Orfao A, van Zelm MC. The nature of circulating CD27+CD43+ B cells. J Exp Med. 2011;208(13):2565-6.

34. Verbinnen B, Covens K, Moens L, Meyts I, Bossuyt X. Human CD20+CD43 + CD27+CD5- B cells generate antibodies to capsular polysaccharides of Streptococcus pneumoniae. J Allergy Clin Immunol. 2012;130(1):272-5.

35. Scholzen A, Sauerwein RW. How malaria modulates memory: activation and dysregulation of B cells in Plasmodium infection. Trends Parasitol. 2013;29(5):252-62

36. Asito AS, Piriou E, Jura WG, Ouma C, Odada PS, Ogola S, et al. Suppression of circulating lgD+CD27+ memory $B$ cells in infants living in a malaria-endemic region of Kenya. Malar J. 2011;10:362.

37. Cunnington AJ, Riley EM. Suppression of vaccine responses by malaria: insignificant or overlooked? Expert Rev Vaccines. 2010;9(4):409-29.

38. Requena P, Campo JJ, Umbers AJ, Ome M, Wangnapi R, Barrios D, et al. Pregnancy and malaria exposure are associated with changes in the $B$ cell pool and in plasma eotaxin levels. J Immunol. 2014;193(6):2971-83.

39. Nduati E, Gwela A, Karanja H, Mugyenyi C, Langhorne J, Marsh K, et al. The plasma concentration of the B cell activating factor is increased in children with acute malaria. J Infect Dis. 2011;204(6):962-70. 
40. Scholzen A, Teirlinck AC, Bijker EM, Roestenberg M, Hermsen CC, Hoffman SL, et al. BAFF and BAFF receptor levels correlate with B cell subset activation and redistribution in controlled human malaria infection. J Immunol. 2014;192(8):3719-29.

41. Jeong $\mathrm{Yl}$, Hong SH, Cho SH, Lee WJ, Lee SE. Induction of IL-10-producing CD1dhighCD5+ regulatory B cells following Babesia microti-infection. PLoS One. 2012;7(10):e46553.

42. Yang $M$, Sun $L$, Wang $S, K o K H, X u H$, Zheng BJ, et al. Novel function of $B$ cell-activating factor in the induction of $\mathrm{IL}-10$-producing regulatory $\mathrm{B}$ cells. J Immunol. 2010;184(7):3321-5.

43. Kumsiri R, Potup P, Chotivanich K, Petmitr S, Kalambaheti T, Maneerat Y. Blood stage Plasmodium falciparum antigens induce $T$ cell independent immunoglobulin production via B cell activation factor of the TNF family (BAFF) pathway. Acta Trop. 2010;116(3):217-26.

44. Weiss GE, Crompton PD, Li S, Walsh LA, Moir S, Traore B, et al. Atypical memory $B$ cells are greatly expanded in individuals living in a malariaendemic area. J Immunol. 2009;183(3):2176-82

45. Muellenbeck MF, Ueberheide B, Amulic B, Epp A, Fenyo D, Busse CE, et al. Atypical and classical memory B cells produce Plasmodium falciparum neutralizing antibodies. J Exp Med. 2013;210(2):389-99.

46. Weiss GE, Clark EH, Li S, Traore B, Kayentao K, Ongoiba A, et al. A positive correlation between atypical memory $B$ cells and Plasmodium falciparum transmission intensity in cross-sectional studies in Peru and Mali. PLoS One. 2011;6(1):e15983

47. Portugal S, Doumtabe D, Traore B, Miller LH, Troye-Blomberg M, Doumbo OK et al. B cell analysis of ethnic groups in Mali with differential susceptibility to malaria. Malar J. 2012;11:162

48. Ehrhardt GR, Davis RS, Hsu JT, Leu CM, Ehrhardt A, Cooper MD. The inhibitory potential of Fc receptor homolog 4 on memory B cells. Proc Nat Acad Sci U S A. 2003;100(23):13489-94.

49. Ehrhardt GR, Hsu JT, Gartland L, Leu CM, Zhang S, Davis RS, et al. Expression of the immunoregulatory molecule $\mathrm{FcRH} 4$ defines a distinctive tissue-based population of memory B cells. J Exp Med. 2005;202(6):783-91.

50. Moir S, Ho J, Malaspina A, Wang W, DiPoto AC, O'Shea MA, et al. Evidence for HIV-associated B cell exhaustion in a dysfunctional memory B cell compartment in HIV-infected viremic individuals. J Exp Med. 2008;205(8):1797-805.

51. Sohn HW, Krueger PD, Davis RS, Pierce SK. FCRL4 acts as an adaptive to innate molecular switch dampening BCR signaling and enhancing TLR signaling. Blood. 2011;118(24):6332-41.

52. Shio MT, Kassa FA, Bellemare MJ, Olivier M. Innate inflammatory response to the malarial pigment hemozoin. Microbes and infection/Institut Pasteur. 2010;12(12-13):889-99.

53. Chaoul N, Burelout $C$, Peruchon $S$, van Buu BN, Laurent $P$, Proust $A$, et al. Default in plasma and intestinal IgA responses during acute infection by simian immunodeficiency virus. Retrovirology. 2012;9:43.

54. Fontaine J, Chagnon-Choquet J, Valcke HS, Poudrier J, Roger M, Montrea Primary HIVI, et al. High expression levels of B lymphocyte stimulator (BLyS) by dendritic cells correlate with HIV-related B-cell disease progression in humans. Blood. 2011;117(1):145-55.

55. Allen JE, Maizels RM. Diversity and dialogue in immunity to helminths. Nat Rev Immunol. 2011;11(6):375-88.

56. Everts B, Adegnika AA, Kruize YC, Smits HH, Kremsner PG, Yazdanbakhsh M. Functional impairment of human myeloid dendritic cells during Schistosoma haematobium infection. PLoS Negl Trop Dis. 2010;4(4):e667.

57. Labuda LA, Ateba-Ngoa U, Feugap EN, Heeringa JJ, van der Vlugt LE, Pires RB, et al. Alterations in peripheral blood B cell subsets and dynamics of B cell responses during human schistosomiasis. PLoS Negl Trop Dis. 2013;7(3):e2094.

58. van der Vlugt LE, Labuda LA, Ozir-Fazalalikhan A, Lievers E, Gloudemans AK, Liu KY, et al. Schistosomes induce regulatory features in human and mouse CD1d(hi) B cells: inhibition of allergic inflammation by IL-10 and regulatory T cells. PLoS One. 2012;7(2):e30883.

59. van der Vlugt LE, Zinsou JF, Ozir-Fazalalikhan A, Kremsner PG, Yazdanbakhsh M, Adegnika AA, Smits HH: Interleukin 10 (IL-10)-Producing CD1dhi Regulatory B Cells From Schistosoma Haematobium-Infected Individuals Induce IL-10Positive T Cells and Suppress Effector T-Cell Cytokines. The Journal of infectious diseases. 2014. 210(8):1207-16

60. Dhiman R, Indramohan M, Barnes PF, Nayak RC, Paidipally P, Rao LV, et al. IL-22 produced by human NK cells inhibits growth of Mycobacterium tuberculosis by enhancing phagolysosomal fusion. J Immunol. 2009;183(10):6639-45.
61. Khader SA, Bell GK, Pearl JE, Fountain JJ, Rangel-Moreno J, Cilley GE, et al $\mathrm{IL}-23$ and IL-17 in the establishment of protective pulmonary CD4+ T cell responses after vaccination and during Mycobacterium tuberculosis challenge. Nat Immunol. 2007:8(4):369-77.

62. Okamoto Yoshida Y, Umemura M, Yahagi A, O'Brien RL, Ikuta K, Kishihara K, et al. Essential role of IL-17A in the formation of a mycobacterial infectioninduced granuloma in the lung. J Immunol. 2010;184(8):4414-22.

63. Maglione PJ, Chan J. How B cells shape the immune response against Mycobacterium tuberculosis. Eur J Immunol. 2009;39(3):676-86.

64. Zhang M, Wang Z, Graner MW, Yang L, Liao M, Yang Q, et al. B cell infiltration is associated with the increased IL-17 and IL-22 expression in the lungs of patients with tuberculosis. Cell Immunol. 2011;270(2):217-23.

65. Zhang M, Zheng X, Zhang J, Zhu Y, Zhu X, Liu H, et al. CD19(+)CD1d(+)CD5 (+) $B$ cell frequencies are increased in patients with tuberculosis and suppress Th17 responses. Cell Immunol. 2012;274(1-2):89-97.

66. Souwer $Y$, Griekspoor A, Jorritsma T, de Wit J, Janssen H, Neefjes J, et al. $B$ cell receptor-mediated internalization of salmonella: a novel pathway for autonomous B cell activation and antibody production. J Immunol. 2009;182(12):7473-81.

67. Nanton MR, Way SS, Shlomchik MJ, McSorley SJ. Cutting edge: B cells are essential for protective immunity against Salmonella independent of antibody secretion. J Immunol. 2012;189(12):5503-7.

68. Shen P, Roch T, Lampropoulou V, O'Connor RA, Stervbo U, Hilgenberg E, et al. IL-35-producing $B$ cells are critical regulators of immunity during autoimmune and infectious diseases. Nature. 2014;507(7492):366-70.

69. Malaspina A, Moir S, Kottilil S, Hallahan CW, Ehler LA, Liu S, et al. Deleterious effect of HIV-1 plasma viremia on B cell costimulatory function. J Immunol. 2003:170(12):5965-72.

70. Moir S, Fauci AS. B cells in HIV infection and disease. Nat Rev Immunol. 2009:9(4):235-45

71. Titanji K, Chiodi F, Bellocco R, Schepis D, Osorio L, Tassandin C, et al. Primary HIV-1 infection sets the stage for important B lymphocyte dysfunctions. Aids. 2005;19(17):1947-55.

72. Amadori A, Chieco-Bianchi L. B-cell activation and HIV-1 infection: deeds and misdeeds. Immunol Today. 1990;11(10):374-9.

73. Lane HC, Masur H, Edgar LC, Whalen G, Rook AH, Fauci AS. Abnormalities of B-cell activation and immunoregulation in patients with the acquired immunodeficiency syndrome. N Engl J Med. 1983;309(8):453-8

74. Muller F, Froland SS, Brandtzaeg P. Altered IgG-subclass distribution in lymph node cells and serum of adults infected with human immunodeficiency virus (HIV. Clin Exp Immunol. 1989:78(2):153-8.

75. Bonsignori M, Alam SM, Liao HX, Verkoczy L, Tomaras GD, Haynes BF, et al. HIV-1 antibodies from infection and vaccination: insights for guiding vaccine design. Trends Microbiol. 2012;20(11):532-9.

76. Kobie JJ, Alcena DC, Zheng B, Bryk P, Mattiacio JL, Brewer M, et al. 9G4 autoreactivity is increased in HIV-infected patients and correlates with HIV broadly neutralizing serum activity. PLoS One. 2012;7(4):e35356.

77. Hart M, Steel A, Clark SA, Moyle G, Nelson M, Henderson DC, et al. Loss of discrete memory $B$ cell subsets is associated with impaired immunization responses in HIV-1 infection and may be a risk factor for invasive pneumococcal disease. J Immunol. 2007;178(12):8212-20.

78. Titanji K, De Milito A, Cagigi A, Thorstensson R, Grutzmeier S, Atlas A, et al. Loss of memory $B$ cells impairs maintenance of long-term serologic memory during HIV-1 infection. Blood. 2006;108(5):1580-7.

79. Peruchon S, Chaoul N, Burelout C, Delache B, Brochard P, Laurent $P$, et al. Tissue-specific B-cell dysfunction and generalized memory B-cell loss during acute SIV infection. PLoS One. 2009:4(6):e5966.

80. He B, Qiao X, Klasse PJ, Chiu A, Chadburn A, Knowles DM, et al. HIV-1 envelope triggers polyclonal Ig class switch recombination through a CD40-independent mechanism involving BAFF and C-type lectin receptors. J Immunol. 2006;176(7):3931-41.

81. Good KL, Avery DT, Tangye SG. Resting human memory B cells are intrinsically programmed for enhanced survival and responsiveness to diverse stimuli compared to naive B cells. J Immunol. 2009;182(2):890-901.

82. Titanji K, Velu V, Chennareddi L, Vijay-Kumar M, Gewirtz AT, Freeman GJ, et al. Acute depletion of activated memory B cells involves the PD-1 pathway in rapidly progressing SIV-infected macaques. J Clin Invest. 2010;120(11):3878-90.

83. Kardava L, Moir S, Wang W, Ho J, Buckner CM, Posada JG, et al. Attenuation of HIV-associated human B cell exhaustion by siRNA downregulation of inhibitory receptors. J Clin Invest. 2011;121(7):2614-24. 
84. Jelicic K, Cimbro R, Nawaz F, da Huang W, Zheng X, Yang J, et al. The HIV-1 envelope protein gp120 impairs B cell proliferation by inducing TGF-beta1 production and FCRL4 expression. Nat Immunol. 2013;14(12):1256-65.

85. Legendre C, Raphael M, Gras G, Lefevre EA, Feuillard J, Dormont D, et al. CD80 expression is decreased in hyperplastic lymph nodes of HIV+ patients. Int Immunol. 1998;10(12):1847-51.

86. Badr G, Borhis G, Treton D, Moog C, Garraud O, Richard Y. HIV type 1 glycoprotein 120 inhibits human B cell chemotaxis to CXC chemokine ligand (CXCL) 12, CC chemokine ligand (CCL)20, and CCL21. J Immunol. 2005;175(1):302-10.

87. Tenner-Racz K, Stellbrink HJ, van Lunzen J, Schneider C, Jacobs JP, Raschdorff B, et al. The unenlarged lymph nodes of HIV-1-infected, asymptomatic patients with high CD4 T cell counts are sites for virus replication and CD4 T cell proliferation. The impact of highly active antiretroviral therapy. J Exp Med. 1998;187(6):949-59.

88. Pantaleo G, Graziosi C, Demarest JF, Cohen OJ, Vaccarezza M, Gantt K, et al Role of lymphoid organs in the pathogenesis of human immunodeficiency virus (HIV) infection. Immunol Rev. 1994;140:105-30.

89. Levesque MC, Moody MA, Hwang KK, Marshall DJ, Whitesides JF, Amos JD, et al. Polyclonal B cell differentiation and loss of gastrointestinal tract germinal centers in the earliest stages of HIV-1 infection. PLoS Med. 2009;6(7):e1000107.

90. Zhang ZQ, Casimiro DR, Schleif WA, Chen M, Citron M, Davies ME, et al. Early depletion of proliferating $B$ cells of germinal center in rapidly progressive simian immunodeficiency virus infection. Virology. 2007;361(2):455-64.

91. Hong JJ, Amancha PK, Rogers K, Ansari AA, Villinger F. Spatial alterations between CD4(+) T follicular helper, B, and CD8(+) T cells during simian immunodeficiency virus infection: T/B cell homeostasis, activation, and potential mechanism for viral escape. J Immunol. 2012;188(7):3247-56.

92. Lindqvist M, van Lunzen J, Soghoian DZ, Kuhl BD, Ranasinghe S, Kranias G, et al. Expansion of HIV-specific T follicular helper cells in chronic HIV infection. J Clin Invest. 2012;122(9):3271-80.

93. Perreau M, Savoye AL, De Crignis E, Corpataux JM, Cubas R, Haddad EK, et al. Follicular helper T cells serve as the major CD4 T cell compartment for HIV-1 infection, replication, and production. J Exp Med. 2013;210(1):143-56.

94. Petrovas C, Yamamoto T, Gerner MY, Boswell KL, Wloka K, Smith EC, et al. CD4 T follicular helper cell dynamics during SIV infection. J Clin Invest. 2012;122(9):3281-94.

95. Yue FY, Lo C, Sakhdari A, Lee EY, Kovacs CM, Benko E, et al. HIV-specific IL-2 producing CD4+ T cells are induced in acute and chronic progressive HIV infection and are associated with relative viral control. J Immunol. 2010;185(1):498-506

96. Xu W, Santini PA, Sullivan JS, He B, Shan M, Ball SC, et al. HIV-1 evades virusspecific $\lg G 2$ and $\lg A$ responses by targeting systemic and intestinal B cells via long-range intercellular conduits. Nat Immunol. 2009;10(9):1008-17.

97. Lefevre EA, Krzysiek R, Loret EP, Galanaud P, Richard Y. Cutting edge: HIV-1 Tat protein differentially modulates the $B$ cell response of naive, memory, and germinal center B cells. J Immunol. 1999;163(3):1119-22.

98. Malaspina A, Moir S, Ho J, Wang W, Howell ML, O'Shea MA, et al. Appearance of immature/transitional B cells in HIV-infected individuals with advanced disease: correlation with increased IL-7. Proc Natl Acad Sci U S A. 2006;103(7):2262-7.

99. Stohl W, Cheema GS, Briggs WS, Xu D, Sosnovtseva S, Roschke V, et al. B lymphocyte stimulator protein-associated increase in circulating autoantibody levels may require CD4+ T cells: lessons from HIV-infected patients. Clin Immunol. 2002;104(2):115-22.

100. Richard Y, Amiel C, Jeantils V, Mestivier D, Portier A, Dhello G, et al. Changes in blood B cell phenotypes and Epstein-Barr virus load in chronically human immunodeficiency virus-infected patients before and after antiretroviral therapy. J Infect Dis. 2010;202(9):1424-34.

101. Gloghini A, Dolcetti R, Carbone A. Lymphomas occurring specifically in HIV-infected patients: from pathogenesis to pathology. Semin Cancer Biol. 2013;23(6):457-67.

102. Pestka JM, Zeisel MB, Blaser E, Schurmann P, Bartosch B, Cosset FL, et al. Rapid induction of virus-neutralizing antibodies and viral clearance in a single-source outbreak of hepatitis C. Proc Natl Acad Sci U S A. 2007;104(14):6025-30.

103. Herkel J, Carambia A. Let it B in viral hepatitis? J Hepatol. 2011:55(1):5-7.

104. Chen M, Sallberg M, Sonnerborg A, Weiland O, Mattsson L, Jin L, et al. Limited humoral immunity in hepatitis $C$ virus infection. Gastroenterology. 1999;116(1):135-43.
105. Doi H, lyer TK, Carpenter E, Li H, Chang KM, Vonderheide RH, et al. Dysfunctional B-cell activation in cirrhosis resulting from hepatitis $C$ infection associated with disappearance of CD27-positive B-cell population. Hepatology. 2012;55(3):709-19.

106. Doi H, Tanoue S, Kaplan DE. Peripheral CD27-CD21- B-cells represent an exhausted lymphocyte population in hepatitis C cirrhosis. Clin Immunol. 2014;150(2):184-91.

107. Oliviero B, Cerino A, Varchetta S, Paudice E, Pai S, Ludovisi S, et al. Enhanced B-cell differentiation and reduced proliferative capacity in chronic hepatitis C and chronic hepatitis B virus infections. J Hepatol. 2011;55(1):53-60.

108. Ducoulombier D, Roque-Afonso AM, Di Liberto G, Penin F, Kara R, Richard Y, et al. Frequent compartmentalization of hepatitis $C$ virus variants in circulating B cells and monocytes. Hepatology. 2004;39(3):817-25.

109. Ito M, Kusunoki H, Mizuochi T. Peripheral B cells as reservoirs for persistent HCV infection. Front Microbiol. 2011;2:177.

110. Toubi E, Gordon S, Kessel A, Rosner I, Rozenbaum M, Shoenfeld Y, et al. Elevated serum B-Lymphocyte activating factor (BAFF) in chronic hepatitis C virus infection: association with autoimmunity. J Autoimmun. 2006;27(2):134-9.

111. Lee BO, Tucker A, Frelin L, Sallberg M, Jones J, Peters C, et al. Interaction of the hepatitis $B$ core antigen and the innate immune system. J Immunol. 2009;182(11):6670-81.

\section{Submit your next manuscript to BioMed Central and take full advantage of:}

- Convenient online submission

- Thorough peer review

- No space constraints or color figure charges

- Immediate publication on acceptance

- Inclusion in PubMed, CAS, Scopus and Google Scholar

- Research which is freely available for redistribution 